\title{
A SEMIOTIC APPROACH TO A LEGAL DEFINITION OF TERRORISM
}

\author{
Susan Tiefenbrun*
}

I. INTRODUCTION $\ldots \ldots \ldots \ldots \ldots \ldots \ldots \ldots \ldots \ldots \ldots \ldots \ldots$

II. ElEMENTS OF THE CRIME OF TERRORISM $\ldots \ldots \ldots \ldots \ldots \ldots 360$

III. THE MANY DEFINITIONS OF TERRORISM $\ldots \ldots \ldots \ldots \ldots . \ldots 363$

A. United States' Definitions of Terrorism . ......... 363

1. United States 1996 Anti-Terrorism Act's

Definition of Terrorism ............... 364

2. The 2001 United and Strengthening America by

Providing Appropriate Tools Required to Intercept and Obstruct Terrorism Act (United States.

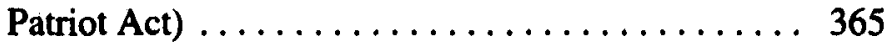

3. The International Money Laundering Abatement and Financial Anti-Terrorism Act of $2001 \ldots \ldots .366$

4. FBI's Definition of Terrorism ............ 367

5. United States State Department's Definition of Terrorism ........................ 367

6. United States State Department's Definition of International Terrorism ............... 368

B. English Definition of Terrorism ............. 368

C. French Definition of Terrorism ............. 370

D. European Nations' Definition of Terrorism ......... 373

E. Canadian Definition of Terrorism ............. 373

F. United Nations' Definitions of Terrorism .......... 375

G. Scholars' Attempts at Definition of Terrorism: ...... 379

* Associate Professor of Law at Thomas Jefferson School of Law.

I would like to thank Professors Aaron Schwabach and Richard Scott of Thomas Jefferson School of Law and Professor Malvina Halberstam of Benjamin N. Cardozo School of Law for reading earlier drafts of this Article. I delivered a shorter version of this Article for a War, Crimes, and Terrorism Conference: The Role of International Courts and Tribunals which I organized at the University of Nice School of Law in France on July 17, 2002. The Conference included Judge Claude Jorda of the International Criminal Tribunal of the Former Yugoslavia, Judge Lucius Caflisch of the European Court of Human Rights, and Judge Rosalyn Higgins of the International Court of Justice, as well as leading scholars in the field such as Professors Catharine MacKinnon, Malvina Halberstam, William Ginsberg, and Norman Silber. A different version of this Article was also delivered at the American Branch of the International Law Association on October 24, 2002 in New York for a panel devoted to September 11th and the War on Terrorism. 
IV. WHAT IS THE DIFFERENCE BETWEEN INTERNATIONAL AND DOMESTIC TERRORISM? . . . . . . . . . . . . . . . 382

V. TERRORISM IS NOT ONLY A CRIME BUT A METHOD TO ACHIEVE SELF-DETERMINATION .............. 383

VI. INTERNATIONAL CRIMES ARE ALSO METHODS OF COMMITTING TERRORISM .................... 385

VII. IF TERRORISM IS NOT ONLY A CRIME, BUT A METHOD OR AN ACT OF WAR, THEN WHAT COURT SHOULD TRY INTERNATIONAL TERRORISTS? . . . . . . . . . . . 386 VIII. THE PARAdOXES INHERENT IN THE MEANING OF TERRORISM. . 387

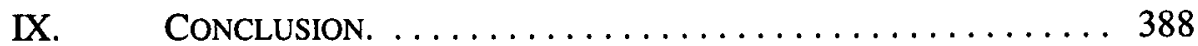

\section{INTRODUCTION}

It is hard to believe that a word like "terrorism," which is used so frequently these days in different contexts and in casual, colloquial, political, and legal discourses, does not have a universally-accepted definition. ' It is not enough to say, as United States Supreme Court Justice Potter Stewart once said of pornography, "we know it when we see it." Terrorism must be deconstructed ${ }^{3}$ to distinguish between domestic and international terrorism, ${ }^{4}$ state-sponsored and non-state sponsored terrorism, and terrorism per se and legal revolutionary violence ${ }^{5}$ that falls within the laws of war. ${ }^{6}$ Semiotics is the

1. M. CHERIF BASSIOUNI, INTERNATIONAL TERRORISM; MULTLATERALCONVENTIONS (1937-2001) 14, n.48 (Transnational Publishers, Inc. 2001) [hereinafter BASSiOUNI]. See also Kevin J. Greene, Terrorism as Impermissible Political Violence: An International Law Framework, 16 VT. L. REV. 461 (1992) ("Terrorism has 'no precise or widely accepted definition."').

2. See Stephen Yagman, Defining the Weapon of Terrorism: Frustrated People Without Another Method Resort to 'Politico-Military' Violence Instead, L.A. Dail Y J., 6 Mar. 12, 2002.

3. See Susan Tiefenbrun, Legal Semiotics, 5, 1 CARDOZO ARTS \& ENT. L.J. 89-156 (1986) (discussing the application of semiotics to the law and the meaning of "deconstruction").

4. In the US Antiterrorism Act of 1990, the United States defines the term "international terrorism" to mean activities that: (A) involve violent acts or acts dangerous to human life that are a violation of the criminal laws of the United States or of any state, or that would be a criminal violation if committed within the jurisdiction of the United States or of any State; (B) appear to be intended (i) to intimidate or coerce a civilian population; (ii) to influence the policy of a government by intimidation or coercion; or (iii) to affect the conduct of a government by assassination or kidnapping; and $(\mathrm{C})$ occur primarily outside the territorial jurisdiction of the United States, or transcend national boundaries in terms of the means by which they are accomplished, the persons they appear intended to intimidate or coerce, or the locale in which their perpetrators operate or seek asylum. (US Antiterrorism Act of 1990, Publ L. No. 101-519, 104 St. 2250 (codified at 18 U.S.C. $\$ 2331$ (Supp. 1991), cited in U.S. FEDERAL LEGAL RESPONSES TO TERRORISM 74-75(Yonah Alexander and Edgar H. Brenner, eds., Transnational Publishers 2002).

5. Yonah AleXander, Michael S. Swetnam and Herbert M. Levine, ETA: Profile Of A TERRORIST GROUP 4 (Transnational Publishers, Inc. 2001). "The ETA proclaims the right of the Basque people to self-rule and the use of the most appropriate means to achieve its goal." Id. at 4.

6. ChristoPher L. BLAKESLEy, TERRORISM, DRUGS, INTERNATIONAL LAW, AND THE PROTECTION 
science of signs ${ }^{7}$. A semiotic approach to the meaning of the term "terrorism" includes an investigation of its hidden meanings, its connotations as well as denotations, in order to expose the deep structure of the term and to unravel its complexities. A semiotic approach is designed to uncover the basic structural elements of the meaning of a term, and each element acts as a sign for the identification of a terrorist act. The elements of the definition are either necessary or sufficient for the act to be deemed a terrorist act.

There are two major obstacles to overcome in order to arrive at a universally-accepted definition of the term. First, it is necessary to distinguish between three different conceptions of terrorism: terrorism as a crime in itself, terrorism as a method to perpetrate other crimes, and terrorism as an act of war. When terrorism is conceived of as a crime, its elements and defenses can be identified and analyzed. When terrorism is conceived of as a method to perpetrate other crimes, terrorism will sometimes overlap with other crimes like crimes against humanity, genocide, war crimes, rape, etc. When terrorism is conceived of as an act of war, the laws of war will cover the legal responses to terrorism. State responses to terrorism require the balancing of a state's right to defend itself proportionally against threats or the illegal use of force or acts of aggression, as included under the United Nations Charter norms. ${ }^{8}$

OF HUMAN LiBERTY 17, 20 (1922). Blakesley defines terrorism as violence aimed at innocents (or noncombatants) to gain an edge over, or to coerce, a third party. This is different from justifiable and legal revolutionary violence, which seeks liberation from oppression or restriction on one's own sovereignty (assuming such acts of revolutionary violence fall within the law of war) (cited in DOUGLAS J. DAvidS, NARCo-Terrorism: A Unified Strategy to Fight A Growing Terrorist Menace 2 (Transnational Publishers, Inc. 2002)). Louis Rene Beres, Article: The Legal Meaning of Terrorism for the Military Commander, CONN. J. INT'L. L. 9 (1995). (Beres argues that the failure of insurgents to comply with the laws of war does not convert these military forces into terrorists but it does make them guilty of war crimes and possibly even crimes against humanity). Cherif Bassiouni argues convincingly that terrorist methods can occur during armed conflict and, therefore, terrorism can be included under war crimes. I maintain that terrorism can be included under war crimes only if the five elements of the definition of terrorism are present.

7. Any attempt here at a definition of semiotics is at best preliminary and partial. See Tiefenbrun, supra note 3, for a history of semiotics as it applies to the law. See also COLLECTED PAPERS OF CHARLES SANDERS PEIRCE 335 (Charles Harshone \& Paul Weiss eds., The Belknap Press of Harvard University 1960). By semiotics or semiosis Peirce means the interplay of three subjects: a sign, its object, and its interpretant. See also Umberto ECO, A TheORY of SEMIOTICS 7 (Indiana University Press 1976), citing Ferdinand de Saussure's definition of semiotics: "a science that studies the life of signs at the heart of society."

8. See U.N.CHARTER art. 2, para. 4: "All members shall refrain in their international relations from the threat or use of force against the territorial integrity or political independence of any state, or in any other manner inconsistent with the Purposes of the United Nations," available at http://www.un.org/Overview/Charter/chapter 1.html (last visited Jan. 31, 2003).

See U.N. CHARTER art. 51: "Nothing in the present Charter shall impair the inherent right of individual or collective self-defense if an armed attack occurs against a Member of the United Nations, until the Security Council has taken measures necessary to maintain international peace and security," available at http://www.un.org/Overview/Charter/chapter7.html (last visited Jan. 31, 2003). 
The second obstacle to overcome in an attempt to arrive at a universallyaccepted definition of the term is the necessity to resolve its underlying paradoxes. Terrorism is a phenomenon steeped in varying and oftentimes conflicting political and ideological beliefs. Given that states have a fundamental right to self-defense and the right to self-determination, is terrorism legitimate if it is perpetrated in self-defense or in an attempt to achieve selfdetermination?

The Article will uncover five basic elements of the crime of terrorism that are deeply embedded in each of the many definitions of terrorism proposed by the United States in its laws, and by many other nations, scholars, and organizations like the United Nations. This Article will attempt to show that under certain circumstances requiring the presence of the basic five elements of the crime, terrorism can be included in other specifically defined international crimes like war crimes, crimes against humanity, and genocide. The Article will also look comparatively at United States, English, French, European, and Canadian definitions of terrorism. It will look closely at the United Nations' attempt to define terrorism in its seventeen multilateral conventions. It will also examine different definitions proposed by leading scholars in the field of international law and the law of terrorism.

This Article will distinguish between international and domestic terrorism and will uncover the existence of three different conceptions of terrorism that have profound implications for the adjudication of terrorist acts. Terrorism is conceived of as a crime, as a method, and as an act of war. These different conceptions of terrorism lead one to question which tribunal would be appropriate to try international terrorists. Finally, the Article will focus on the paradoxes inherent in the concept of terrorism. The paradoxical nature of terrorism complicates the establishment of a universally-accepted definition of the term.

\section{ELEMENTS OF THE CRIME OF TERRORISM}

Black's law dictionary defines terrorism as: "the use or threat of violence to intimidate or cause panic, esp. as a means of affecting political conduct.", Scholars have attempted to further define the term, ${ }^{10}$ resulting in many different definitions of terrorism ${ }^{11}$ that can all be reduced to five basic structural elements: ${ }^{12}$

9. Black's Law Dictionary 1484 (7th ed. 1999).

10. DAVIDS, supra note 6, at 2.

11. See infra Emanuel Gross, Legal Aspects of Tackling Terrorism: The Balance Between the Right of a Democracy to Defend thself and the Protection of Human Rights, 6 U.C.L.A. J. INT'L L. \& FOR. AFF. 89 (2001).

12. See ld. "It is difficult to classify the term "terrorism" or provide it with a clear definition or 
1) The perpetration of violence by whatever means;

2) The targeting of innocent civilians;

3) With the intent to cause violence or with wanton disregard for its consequences;

4) For the purpose of causing fear, coercing or intimidating an enemy;

5) In order to achieve some political, military, ethnic, ideological, or religious goal. ${ }^{13}$

Normally the violence associated with terrorism is perpetrated without justification or without excuse in an aim to gain publicity for the cause. ${ }^{14}$ In this sense terrorism is similar to extreme forms of civil disobedience ${ }^{15}$ in which the perpetrators resort to violence in order to gain publicity for a cause that is presumably an unjust law or societal oppression. Normally state-sponsored terrorists do not seek publicity whereas individual terrorists thrive on publicity for their cause. ${ }^{16}$ State responses to acts of civil disobedience have sometimes resulted in the use of force. Similarly, the peacetime use of terrorism by a state against passive resistance is arguably justified in order to maximize compliance to a new state policy. ${ }^{17}$ This Article will attempt to show that terrorism in any form and for whatever reason is unjustified.

The structural elements of the definition of terrorism need further analysis. What actually constitutes "violence?" The dictionary definition of violence includes unjust or unwarranted use of force, usually accompanied by fury, vehemence, or outrage; physical force unlawfully exercised with the intent to harm. ${ }^{18}$ But there is a broad spectrum to the definition of "violence." Some

interpretation ...Nonetheless, the majority of the definitions have a common basis-terrorism is the use of violence and the imposition of fear to achieve a particular purpose, generally entailing the aspiration to overthrow an existing regime, or fight it, and where the persons forming the group organize in a tightly controlled structure ...need to determine whether the activities of the particular group are morally supported by the state."

13. These basic five elements are a variation of Blakesley's elements. BLAKELSEY, supra note 6, at 37. Blakesley's five elements include "conducting the above acts without justification or excuse" and do not include "ethnic or ideological" goals (termed "benefits" in Blakesley's listing). Blakesley's elements do not include the word "fear" which is key to the definition of the term "terrorism".

14. See Walter Laqueur, Reflections on Terrorism, FoREIGN AfFAIRS 65 (1986) at 86-88 (cited in DAvidS, supra note 6, at 2).

15. See Susan W. Tiefenbrun, Classic Greek Themes in Contemporary Law: On Civil Disobedience, Jurisprudence, Feminism and the Law in the Antigones of Sophocles and Anouilh, 11 CARDOzo STUD. L. \& LIT. 35 (1999), and Susan Tiefenbrun, Semiotics and Martin Luther King's "Letter from Birmingham Jail," 2 CARDozo Stud. L. \& LIT. 255-87 (1992).

16. BASSIOUNI, supra note 1, at 29.

17. Id. at 32 .

18. BLACK'S LAW DICTIONARY, supra note 9, at 1564. 
courts have held that violence is not limited to physical contact or injury, but may include picketing in a labor dispute conducted with misleading signs, false statements, erroneous publicity, and veiled threats by words and acts. ${ }^{19}$ Violence has many forms and degrees of severity. However, an act is violent only if it causes harm to persons and things. ${ }^{20}$ Violence in any form can inspire terror in its victims and in those indirectly affected by the violence.

What is an "innocent civilian?" There is no agreement as to who is actually included in this category, ${ }^{21}$ but one is tempted to say "we know an innocent civilian when we see one." If only one innocent civilian is killed or seriously injured during an act of war motivated by self-defense, will this be enough to call it a "terrorist" act? What are the legitimate defenses of the unintentional killing of an innocent civilian during wartime? Is collateral damage of the use of force during wartime a legitimate defense to killing innocent civilians? These are only some of the questions that the element of violence against "innocent civilians" raises in proposing a universally-accepted definition of terrorism.

The element of intent or wanton disregard is less troublesome because of established definitions used by the courts to determine the mental state of an accused. What is more troublesome is the element of "fear" which is not a legal term but a psychological phenomenon that is manifested by various signs and symptoms such as trembling, shaking, sweaty palms, etc. Intimidation, which was established as a tort in England as early as $1964,{ }^{22}$ is unlawful coercion that produces harm.

The manifold purposes of terrorism include the accomplishment of a political, military, ethnic, ideological, or religious cause. The overriding purpose is a necessary element of the definition. Political, ethnic, ideological and religious goals are not troublesome within the definition of terrorism. However, the accomplishment of a "military goal" is controversial. If a military goal is added to the definition of terrorism, this inclusion places a burden on combatants never to use terrorism during wartime. Individuals, small groups, and states have been known to commit terrorist acts in the context of wars of national liberation. ${ }^{2.3}$

19. Id.

20. BASSIOUNI, supra note 1 , at 8 .

21. Id. at 15.

22. Rookes v. Barnard, 1 Lloyd's Rep 28 (H.L. 1964).

23. BASSIOUNI, supra note 1, at 19. See also Jordan Paust, Use of Armed Force Against Terrorists in Afghanistan, Iraq, and Beyond 35 CORNELL. INT'L L.J. 533 (2002). 


\section{THE MANY DEFINITIONS OF TERRORISM}

Even though there are many definitions of terrorism ${ }^{24}$ available for legislative purposes, "terrorism" per se has never been explicitly defined in any of the seventeen existing multilateral anti-terrorism conventions. ${ }^{25}$ Moreover, the multilateral conventions are not applicable to state-sponsored terrorism. They apply only to terrorism committed by individual actors. The absence of a universally-accepted definition of terrorism and the inapplicability of multilateral anti-terrorism legislation to state-sponsored terrorism reflect the deeply political nature of the term terrorism and the absence among nations of commonly shared values ${ }^{26}$ about the rule of law, the legitimacy of goals, and the means to achieve these goals. For example, the international community cannot agree on whether "innocent civilian" is a necessary or simply a sufficient element of the definition. It also cannot agree on who should be included in the category of "innocent civilians" or "diplomats" or "civilian installations" or "legitimate targets." 27 The international community cannot agree on whether terrorism is illegal under all situations or whether it is sometimes permissible in order to achieve a legitimate goal. Some international organizations proclaim that the right to self-rule legitimizes the use of the most appropriate means, including terrorism, to achieve the goals of liberation and independence. ${ }^{28}$

\section{A. United States' Definitions of Terrorism}

In the United States there is a general confusion about what constitutes terrorism. ${ }^{29}$ The United States has shifted its conception of terrorism as a

24. Id. at 15. Bassiouni provides a long list of scholarly articles that attempt to define the term "terrorism." See also John F. Murphy, The Future of Multilateralism and Efforts to Combat International Terrorism, 25 COL. J. TRANS'L L. 35 (1986) and Thomas M. Franck \& Bert B. Lockwood, Preliminary Thoughts Towards an International Convention on Terrorism, 68 AM. J. INT'L L. 69, 70-72 (1974).

25. BASSIOUNI, supra note 1, at xxvi. In the Convention for the Suppression of the Financing of Terrorism, Article 2.l(b), U.N. Doc. A/54/109 (9 De. 1999), there is an indirect definition of terrorism proposed: "Any other act intended to cause death or serious bodily injury to a civilian, or to any other person not taking an active part in the hostilities in a situation of armed conflict, when the purpose of such act, by its nature or context, is to intimidate a population, or to compel a government or an international organization to do or to abstain from doing any act." Id.

26. Id. at 15 .

27. Id.

28. ALEXANDER, SWETNAM, \& LEVINE, supra note 5, at 4: ("Between 1963 and 1965 the terrorist organization adopted the principles of revolutionary war because it was influenced by the successes of the independence war in Algeria and the Cuban revolution. Marxist theory was predominant in its ideology. ETA's purpose was to change the state through an uprising of the people, the destruction of the oppressor state, and finally, the assault to power." $I d$. at 6 .

29. TERRORISM AND THE LAW 3 (Yonah Alexander and Edgar H. Brenner, eds., Transnational Publishers, Inc. 2001). 
"crime" to terrorism as an "act of war." ${ }^{30}$ In the past, the United States classified international terrorism as a crime and applied legal means as the primary tool to fight it. ${ }^{31}$ More recently, however, the United States has moved away from reactive counter-terrorism law enforcement methods towards more proactive techniques to fight international terrorism. This shift has occurred because the United States now perceives terrorist acts as acts of war. ${ }^{32}$ In its war against terrorism, the United States now uses expanded law enforcement and intelligence agencies like the FBI and the CIA to fight terrorism, and these agencies have their own definitions of terrorism.

In the United States federal system, each state determines what constitutes an offense under its domestic criminal or penal code. States define terrorism generically as a crime. For example, the Arkansas Criminal Code provides that "a person commits the offense of terroristic[sic] threatening if, with the purpose of terrorizing another person, he threatens to cause death or serious physical injury or substantial property damage to another person." 33

The United States Congress has not been able to reach a consensus on a working definition of terrorism. ${ }^{34}$ The executive branch has also not developed a coordinated position on the meaning of the term. ${ }^{35}$ The absence of a generally-accepted definition of terrorism in the United States allows the government to craft variant or vague definitions which can result in an erosion of civil rights and the possible abuse of power by the state in the name of fighting terrorism and protecting national security.

\section{United States 1996 Anti-Terrorism Act's Definition of Terrorism}

In the 1996 United States Antiterrorism Act and Effective Death Penalty Act, ${ }^{36}$ the United States defines international terrorism as:

30. Malvina Halberstam, The US Right to Use Force in Response to the Attacks on the Pentagon and the World Trade Center, 9 CARDOZo J. INT'L \& COMP. L. 101 (2001), "Terrorism is a form of war, probably the most serious form of war used against the United States since World War II, if not ever." See also Malvina Halberstam, Terrorist Acts Against and on Board Ships, 331 ISR. Y.B. HUM. RTS. (1987); Malvina Halberstam, Terrorism on the High Seas: The Achille Lauro, Piracy and the IMO Convention on Maritime Safety, 82 AM. J. INT'L L. 269 (1988); Malvina Halberstam, The Evolution of the United Nations Position on Terrorism: From Exempting National Liberation Movements to Criminalizing Terrorism Whenever and By Whomever Committed (COLUMBIA J. ON TRANSNATIONAL LAW, forthcoming 2003).

31. Tyler Raimo, Notes and Comments, Winning at the Expense of Law: The Ramifications of Expanding Counter-Terrorism Law Enforcement Jurisdiction Overseas, 14 AM. U. INT'L. L. REV.1473, 74 (1999) [hereinafter Raimo].

32. Id.

33. ARK. CODE ANN. § 5-13-301 (Michie 2002).

34. Raimo, supra note 31, at 4.

35. Id.

36. Jason Binimow \& Amy Bunk, Annotation, Validity, Construction, and Operation of "Foreign Terrorist Organization" Provision of Anti-Terrorism and Effective Death Penalty Act (AEDPA), 8 U.S.C.A. 
the unlawful use of violence against the United States, citizens of the United States or any other nation, outside the boundaries of the United States, apparently intended to intimidate or coerce a civilian population, influence government policy, or to affect the conduct of a government for political or social objectives. ${ }^{37}$

This definition includes the five basic elements outlined above, but does not list specific terrorist acts that can be classified as criminal. ${ }^{38}$ The advantage of not listing specific acts as "terrorist acts" is that as new forms of technology are created, new forms of terrorist acts are likely to develop, and this law will still cover these news modalities. The disadvantage of not listing specific acts as "terrorist acts" is that the decision will be left up to policy makers to determine who is and who is not committing "terrorist acts." A subjective definition leaves too much room for political bias to affect the decision.

Despite the presence of a definition of terrorism in the United States 1996 Antiterrorism Act, some civil libertarians have attacked this law, basing their objection on a dubious claim that the Act does not contain a definition of terrorism. A more valid claim might be that the United States Antiterrorism Act of 1996 does not explicitly designate specific acts that constitute terrorism. Civil libertarians have expressed a legitimate fear that the alleged absence of a definition will have the following deleterious result: “'Terrorism' is whatever the Secretary of States decides it is ...the Secretary of State may designate a foreign group as a terrorist organization if the Secretary of State finds that the group 'engages in terrorist activity' that threatens the security of United States nationals or the national security of the United States." ${ }^{39}$ The absence of a universally-accepted definition of terrorism and the failure to list specific acts as terrorist acts could cause this bad result to happen in other countries besides the United States.

2. The 2001 United and Strengthening America by Providing Appropriate Tools Required to Intercept and Obstruct Terrorism Act (United States Patriot Act) $)^{40}$

The President of the United States has defined terrorism in a recent antiterrorism act known as the United States Patriot Act. The definition is as

$\S l l 89,178$ A.L.R. FED. 535 (2002). See also U.S. Antiterrorism Act of 1990, 18 U.S.C. $\$ 2331$ (1991).

37. RaIMO, supra note 31 , at 4.

38. Id. at n. 46.

39. JAMES X. DEMPSEY \& DAvid COLE, Terrorism \& THE CONSTITUTION: SACRIFICING CiviL LiberTies IN THE NAME OF NATIONAL SECURITY 119 (First Amendment Foundation 1999) [hereinafter DEMPSEY]. See also Binimow \& Bunk, supra note 36.

40. USA Patriot Act, Pub.L.No. 107-56, 115 Stat. 296-342 (2001). 
follows: "For crimes to be defined as 'terrorist acts' the government must show that they were calculated to influence or affect the conduct of government by intimidation or coercion or to retaliate against government conduct."

This definition requires insight into the mental state of the perpetrator, does not specifically identify the necessary element of violence, and reduces the purpose clause to achieving political goals (i.e., influencing government conduct).

Some civil libertarians have objected to the erosion of civil liberties in the 2001 United States Patriot Act because it authorizes executive detention on the mere suspicion that an immigrant has at some point engaged in a violent crime or provided humanitarian aid to a proscribed organization. This provision authorizes guilt by association and gives the government the power to deny entry to aliens for reasons that are arguably "pure speech" acts. ${ }^{41}$

\section{The International Money Laundering Abatement and Financial Anti-Terrorism Act of 2001}

The United States Financial Anti-Terrorism Act of 2001, which is the counterpart of the United Nations International Convention for the Suppression of the Financing of Terrorism (1999), ${ }^{42}$ was signed into law on October 26, 2001, as Title III of the United States Patriot Act. This statute requires the Secretary of the Treasury to implement numerous changes under a strict timetable in order to follow the trail of those who finance terrorism. Due diligence measures require the identification of beneficial owners of bank accounts. $^{43}$

The United States has designated a variation on the domestic form of "terrorism" called "global terrorism." For example, President Bush signed Executive Order 13244 on September 23, 2001, requiring United States persons to block the assets of a new category of sanctioned parties, known as "specially designated global terrorists (SDGTS)." This category includes individuals, organizations, charities, and business entities. It includes United States persons, United States citizens and permanent residents, United States corporations, and their non-United States branches. The Office of Foreign Assets Control of the United States Department of the Treasury will implement the executive order. The President has threatened to freeze assets and transactions of banks and other financial institutions that refuse to share information about terrorists. ${ }^{44}$ An

41. DEMPSEY, supra note 39.

42. See International Convention for the Suppression of the Financing of Terrorism, Dec. 9, 1999, 39 I.L.M. 270 (2000).

43. Edward J. Krauland and Stephane Lagonico, The New Counter-Money Laundering and AntiTerrorist Financing Law, INT'L L. NEws 1 (2002).

44. Executive Order on Terrorist Financing, available at http://www.whitehouse.gov/news/releases/ 
action to freeze assets was also taken by the United Nations Security Council in Resolution 1267 on October 15, 1999, under Chapter VII of the United Nations Charter. Similar actions were taken against Osama bin Laden on December 19, 2000 pursuant to Security Council Resolution $1333 .{ }^{45}$

\section{FBI's Definition of Terrorism}

Since 1980, the Federal Bureau of Investigation (FBI) has defined terrorism as: "the unlawful use of force or violence against persons or property to intimidate or coerce a government, the civilian population, or any segment thereof, in the furtherance of political or social objectives." 46

The FBI's definition does not include the basic five elements because it omits the necessary element of intent and limits the purpose to the achievement of "political or social objectives." Moreover, the definition does not specifically include or exclude state-sponsored terrorism. If the definition of terrorism does not include the element of intent to coerce or intimidate, then any criminal, like the Son of Sam, who kills just for the sake of bloodthirsty violence, could be deemed a terrorist.

\section{United States State Department's Definition of Terrorism}

The United States Department of State defines the term "terrorism" as: "premeditated, politically motivated violence perpetrated against noncombatant targets by sub-national groups or clandestine agents, usually intended to influence an audience." 47

This definition includes all five elements and the requisite intent, but it limits the purpose to "politically motivated" goals. The United States State Department's definition arguably excludes terrorism committed by a state because it lists only "sub-national groups or clandestine agents." However, if the term "agents" refers to "agents of the state," then state-sponsored terrorism is included in this definition.

2001/09/20010924-1.html (last visited Jan. 31, 2003).

45. Peter D. Trooboff, Antiterrorism Measures, THE NAT'L L.J. Al9 (2001).

46. United States Department of Justice, FBI, Terrorism in the United States, 1988 (Terrorist Research and Analytical Center, Counter-terrorism Section, Criminal Investigative Division, December 31, 1988), at 34, cited in TERRORISM AND THE LAW, supra note 29, at 4, n 7.

47. 22 U.S.C. Section 2656f(d), cited in TERRORISM AND THE LAW, supra note 29, at 4. 


\section{United States State Department Definition of International Terrorism}

The United States Department of State defines the term "international terrorism" as: "terrorism involving citizens of the territory of more than one country." 48

The requirement of more than one country in the United States State Department definition refers to both perpetrators and victims. The State Department also defines the term "terrorist group" to mean "any group practicing, or that has significant subgroups that practice international terrorism." 49 Since international terrorism refers back to "terrorism," which includes only sub-national groups or clandestine agents, arguably the United States State Department definition of international terrorism does not cover state-sponsored terrorist acts, unless the term "agents" refers to the state.

\section{B. English Definition of Terrorism}

The United Kingdom has undergone an evolutionary process in the definition of terrorism. The English defined terrorism in the English Prevention of Terrorism (Temporary Provision) Act of $1984^{50}$ and in the English Prevention of Terrorism (Temporary Provision) Act of $1989^{51}$ : "Terrorism means the use of violence for political ends and includes any use of violence for the purpose of putting the public or any section of the public in fear."

This definition is overly broad, does not include the element of intent, expansively includes "civilians" in the category of "any section of the public"(which could include combatants), and limits the goal to "political" benefit. The perpetration of violence without a requirement of intent could produce odd results. For example, demonstrators for a political cause that end up in a brawl might be deemed "terrorists." An accidental killing by the police or by the army, which is hardly an act of terror, might fall within this definition of terrorism. ${ }^{52}$

In 1996 Lord Lloyd defined terrorism as: "The use of serious violence against persons or property or the threat to use such violence, to intimidate or coerce a government, the public, or any section of the public, in order to promote political, social, or ideological objectives." ${ }^{53}$

48. Id.

49. Id. See 17 YONAH Alexander \& DONALD J. MUSCH, TERRORISM DOCUMENTS OF INTERnational AND LOCAL CONTROL, 170-71 (Oceana Publications, Inc. 1999).

50. English Prevention of Terrorism (Temporary Provision) Act of 1984, Section 14(1).

51. English Prevention of Terrorism Act of 1989, Section 20(1). available at http://www.hmso.gov.uk/acts/acts 1989/Ukpga_19890004_en_6.htm (last visited Feb. 1, 2003). See Gross, supra note 11 at fn. 20.

52. See Gross, supra note 11, at n. 20.

53. See Lord Lloyd, Inquiry into Legislation Against Terrorism, H.L., March 1996 (cited in 
This definition remedies the earlier one that placed limitations on goals, modifies the act of violence by describing it as "serious violence," maintains the element of "civilians" in the broad category of "any section of the public" but still falls short of including an element of intent.

In the 1999 Prevention of Terrorism Bill, the British government defined terrorism even more broadly to include expressions of extremism by groups such as the Animal Liberation Front that had only one issue as its cause. The more recent United Kingdom Terrorism Act of $2000^{54}$ defines terrorism in Section 1(1):

Terrorism means the use or threat of action where the action falls within subsection (2) (i.e. violence, serious damage, endangering life, etc.) and (b) the use or threat is designed to influence the government or to intimidate the public or a section of the public, and (c) the use or threat is made for the purpose of advancing a political, religious or ideological cause.

Terrorist action is further defined in Section 1(2) as:

Acts involving serious violence against a person, serious damage to property, acts that endanger a person's life, other than that of the person committing the action; acts that create a serious risk to the health or safety of the public or a section of the public, or acts designed seriously to interfere with or disrupt an electronic system. ${ }^{55}$

Thus, English law continues to omit the element of intent in its definition of terrorism. United Kingdom law specifically lists certain acts that are terrorist acts, like environmental terrorism, biological terrorism, and even computer hacking. English law on terrorism is extraterritorial and covers terrorist actions outside the United Kingdom and committed by governments of a country outside the United Kingdom. ${ }^{56}$

As a matter of comparative law, United States law and United Kingdom law are quite different with regard to the definition of terrorism. The United Kingdom Terrorism Act of 2000 provides a broad definition of the criminal act of terrorism ("serious violence against a person, serious damage to property, acts that endanger a person's life") and also specifically names certain terrorist acts ("acts that create a serious risk to the health or safety of the public ...or disrupt an electronic system"). In contrast, the United States 1996 Antiterrorism

TERRORISM AND THE LAW, supra note 29, at 4-5).

54. United Kingdom Terrorism Act of 2000, Ch. $11 \S 1$ (1) (July 20, 2000).

55. TERRORISM AND THE LAW, supra note 29, at 4-5.

56. Id at 6 . 
Act includes the element of intent but softens the requirement by adding the adverb "apparently" to the element of intent ("apparently intended to intimidate or coerce a civilian population...."). The United States law on terrorism does not specifically list the acts that constitute terrorist criminal acts.

The English approach to terrorism may have odd but beneficial results. If Greenpeace were to threaten to disrupt a government computer system (e.g. in order to put pressure on Iraq for dealing with its Kurd population in an inhumane manner), the Greenpeace movement would be committing an act of terrorism. ${ }^{57}$ As odd as this result may seem given its laudable purpose, in my view the identification of the Greenpeace organization's act as a terrorist act would be correct in this instance because terrorist acts are not justified, even if they are committed for humanitarian purposes.

\section{French Definition of Terrorism}

The French coined the term "terrorism" during the French revolution, ${ }^{58}$ in the period that followed the fall of Robespierre in 1793-1794, under the infamous Reign of Terror. ${ }^{59}$ The French define terrorism in the dictionary as "violence committed by an organization in order to create a climate of insecurity or in order to overthrow the established government." 60 This definition eliminates the elements of intent and harm to innocent civilians and limits the purpose to the achievement of political goals. In France the term terrorism is also included under the definition of crimes against humanity. As a result of the famous Klaus Barbie case, ${ }^{61}$ a new law defining crimes against humanity had to be adopted in the French Criminal Code. The term "terrorism" is also specifically defined in the French Criminal Code. ${ }^{62}$

57. $\quad$ Id

58. David B. Kopel and Joseph Olson, Preventing a Reign of Terror: Civil Liberties Implications of Terrorism Legislation; 21 OKLA. CITY U.L. REV. 247, 251 (1996). The term "terrorism" was conceived during the French Revolution when the government created a reign of terror to execute political opponents, requisition their property, and impose terror over the remainder of the population until they yielded to the government.

59. Le Petit Larousse (1991 ed.) and Le Petit Robert (1972 ed.).

60. Id.

61. See Leila Sadat Wexler, The Interpretation of the Nuremberg Principles by the French Court of Cassation: From Touvier to Barbie and Back Again, 32 COLUM. J. TRANSNAT'L L. 289 (1994). As a result of the French court decision in the Barbie case, the court found that to be guilty of a crime against humanity one had to intend to take part in carrying out a common plan by systematically committing inhumane acts and illegal persecutions in the name of a state practicing a hegemonic political ideology. Since Vichy, France could not be considered a hegemonic state, Touvier could not, as a matter of law, have committed a crime against humanity. Sadat points out that there is no requirement to prove a "hegemonic state." As a result of this case, a new French Criminal Code defining crimes against humanity was adopted. However, nowhere in this definition is "terrorism" specifically mentioned.

62. French Criminal Code, Article 421-1 (Loi No. 96-647 du 22 juillet 1996 art. 1 Journal Officiel 
"Acts are terrorist acts when they are intentionally committed by an individual entity or by a collective entity in order to seriously disturb law and order by intimidation or by terror."

Unlike the United States law, which does not list particular acts as terrorist acts, the French law specifically names and describes the acts that constitute terrorism. Article 421-1 of the French Criminal Code lists the following acts as terrorist acts:

Attempted murder, assault, kidnapping, hostage-taking on airplanes, ships, all means of transport, theft, extortion, destructions, and crimes committed during group combat, the production or ownership of weapons of destruction and explosives including the production, sale, import and export of explosives, the acquisition, ownership, transport of illegal explosive substances, the production, ownership, storage, or acquisition of biological or chemical weapons, and money laundering.

Article 421-2 of the French Criminal Code ${ }^{64}$ continues the list of terrorist acts to include environmental terrorism: “...Placing in the air, on the ground, under the ground and in the water (including territorial water) any substance that would put the health of man and animals or the environment in danger."

Article 421-2-1 of the French Criminal Code ${ }^{65}$ makes it illegal to belong to or participate in a group that is formed for the purpose of planning one of the terrorist acts named above.

Article 421-2-2 of the French Criminal Code ${ }^{66}$ makes it illegal for anyone to finance a terrorist organization by intentionally providing funds, collecting funds, or managing funds of any value whatsoever, or by giving advice for the purpose of financing terrorism, if that person knows that these funds are going to be used fully or partially for the purpose of committing terrorist acts, and whether or not the terrorist act actually occurs.

du 23 juillet 1996) (Loi No.98-467 du 17 juin 1998 art. 84 Journal Officiel du 18 juin 1998) (Loi No. 2001-1062 du 15 novembre 2001 art. 33 Journal Officiel du 16 novembre 2001). See http://222.legifrance.gouv.fr/html frame_codes 1. htm.

63. Translations of Article 421-1 and other pertinent Articles of the French Criminal Code are provided by Susan Tiefenbrun. The term "ordre public" refers to "public policy" or to "law and order."

64. Article 421-2 of the French Criminal Code (Loi No 96-647 du 22 juillet 1996 art. 2 Journal Officiel du 23 juillet 1996).

65. Article 421-2-1 of the French Criminal Code (Loi No. 96-647 du 22 juillet 1996 art. 3 Journal Officiel du 23 juillet 1996).

66. Article 421-2-2 of the French Criminal Code (Loi No 2001-1062 du 15 novembre 2001 art. 33 Journal Officiel du 16 novembre 2001). 
Article 421-3 of the French Criminal Code ${ }^{67}$ sets forth penalties ranging from six years to life imprisonment for the commission of a terrorist act. Article 421-4 of the French Criminal Code $^{68}$ adds monetary penalties to the prison sentence. For example, if the terrorist is convicted to fifteen years of imprisonment, he or she might also be required to pay a monetary penalty of 225,000 Euros. If an alleged terrorist is convicted of killing one or several people, he or she would be sentenced to imprisonment for life and would be required to pay a penalty of 750,000 Euros. Article $421-5$ of the French Criminal Code ${ }^{69}$ provides that an alleged terrorist who is convicted for ten years of imprisonment must also pay a penalty of 225,000 Euros.

Article 422-1 of the French Criminal Code ${ }^{70}$ provides an exemption for informants. Anyone who had attempted to commit a terrorist act and who, having informed the administrative and judicial authorities in advance of the commission of the act, facilitated the avoidance of the terrorist act and the identification of the other guilty parties will be immune from imprisonment and penalties.

Article 422-2 of the French Criminal Code permits the reduction of a prison sentence by half for anyone who committed a terrorist act or aided in a terrorist act if that person, by warning or informing the administrative or judiciary authorities, enabled the terrorist act to be avoided, or enabled anyone's death or permanent injury to be avoided, or provided the names of the other guilty parties. A life sentence will be reduced to twenty years for such assistance.

Article $422-5$ of the French Criminal Code expressly requires that corporations ("personnes morales") engaging in terrorist activities pay monetary penalties. Article 422-6 of the French Criminal Code ${ }^{71}$ includes confiscation of property as a penalty for any person or corporation engaging in terrorist activity.

Article $422-7$ of the French Criminal Code ${ }^{72}$ provides that any financial penalties imposed on the terrorists will be given to the victims' funds.

67. Article 421-3 of the French Criminal Code (Loi No 96-647 du 22 juillet 1996 art. 4 Journal Officiel du 23 juillet 1996).

68. Article 421-4 of the French Criminal Code (Ordonnance No. 2000-916 du 19 septembre 2000 art. 3 Journal Officiel du 22 septembre 2000 en vigueur le ler janvier 2002).

69. Article 421-5 of the French Criminal Code (Loi No. 96-647 du 22 juillet 1996 art. 5 Journal Officiel du 23 juillet 1996)(Loi No. 2001-1062 du 15 novembre 2001 art. 33 Journal Officiel du 16 novembre 2001)(Ordonnance No 2000-916 du 19 septembre 2000 art. 3 Journal Officiel du 22 septembre 2000 en vigueur le ler janvier 2002).

70. Article $422-1$ of the French Criminal Code.

71. Article 422-6 of the French Criminal Code (Loi No. 2001-1062 du 15 novembre 2001 art. 33 Journal Officiel du 16 novembre 2001).

72. Article 422-7 (Loi No. 2001-1062 du 15 novembre 2001 art. 33 Journal Officiel du 16 novembre 2001). 
Article 434-2 of the French Criminal Code ${ }^{73}$ imposes five years of imprisonment and a fine of 75,000 Euros on anyone attempting to harm the fundamental interests of the nation by a terrorist act.

Article 434-6 of the French Criminal Code ${ }^{74}$ imposes a penalty of three years imprisonment and 45,000 Euros for anyone aiding a terrorist convicted of ten years of imprisonment. Aiding and abetting may be simply offering a terrorist lodging, subsidies, means of subsistence or any other form of assistance. The penalty for aiding and abetting can be increased to five years of imprisonment and 75,000 Euros. However, relatives of the terrorist (parents, brothers, sisters and their spouse) and the spouse of the terrorist or the person with whom the terrorist is living are not included in the list of aiders and abetters.

\section{European Nations' Definition of Terrorism}

The European Convention on the Suppression of Terrorism ${ }^{75}$ was signed by 17 out of 19 member states of the Council of Europe in January 1977. According to this treaty, all states must treat assassination, hostage taking, bomb attacks, and hijacking (major terrorist offenses), as "common crimes" and can not refuse extradition. However, an escape clause was inserted into the European Convention on the Suppression of Terrorism permitting the contacting state to reserve the right to regard a certain offense as a political one. This escape clause would enable that state to withhold extradition. The member states of the European Union strengthened this provision by the European Convention on Extradition. ${ }^{76}$

\section{E. Canadian Definition of Terrorism}

Canada has recently made strong legislative proposals in an attempt to combat terrorism. The Canadian Anti-terrorism Act takes aim at terrorist groups, but also seeks to strike an appropriate balance between respecting Canadian values of fairness and respect for human rights while protecting Canadians and the global community from terrorism. This balance is

73. Article 434-2 (Ordonnance No. 2000-916 du 19 septembre 2000 art. 3 Journal Officiel du 22 septembre 2000 en vigueur le ler janvier 2002).

74. Article 434-6 (Loi No. 96-647 du 22 juillet 1996 art. 7 Journal Officiel du 23 juillet 1996) (Ordonnance No. 200-916 du 19 septembre 2000 art. 3 Journal Officiel du 22 septembre 2000 en vigueur le ler janvier 2002).

75. European Convention on Suppression of Terrorism (Jan. 27, 1977), available at http://www.ciaonet.org/cbr/cbr00/video/cbr_ctd/cbr_ctd_39.html (last visited Feb. 1, 2003).

76. Paul Wilkinson, Terrorism Versus Democracy: The Liberal State Response 193 (Frank Cass 2001). 
accomplished by providing what the Canadian Department of Justice refers to as checks and balances in the form of "clear definitions"

Terrorist activities in Canada have always been treated as criminal offenses. Under the Canadian Criminal Code terrorists can be prosecuted for hijacking, murder, and other acts of violence. The Government of Canada has signed all 12 United Nations Conventions and Protocols ${ }^{78}$ related to terrorism and has ratified 10 , including those that protect against harming aircraft, civil aviation and airports, international shipping, internationally protected persons and diplomats, the safety of nuclear material, and the prevention of the taking of hostages and terrorist bombings. According to the Justice Department, Canada plans to ratify the remaining two United Nations counter-terrorism conventions dealing with the suppression of terrorist financing and the suppression of terrorist bombings. Canada also expects to ratify the Convention on the Safety of United Nations and Associated Personnel Convention (1994), ensuring the safety of United Nations personnel, including peacekeepers, from attacks against their person, official premises, private accommodation and modes of transport. Canada proposes to amend its Criminal Code to implement these United Nations Conventions and to establish provisions aimed at disabling and dismantling the activities of terrorist groups and those who support them.

Canadian law defines a "terrorist activity" in the Criminal Code as an action that takes place either within or outside of Canada that "is an offense under one of the ten United Nations anti-terrorism conventions and protocols; or is an action": "taken or threatened for political, religious, or ideological purposes and threatens the public or national security by killing, seriously harming or endangering a person, substantial property damage that is likely to seriously harm people or by interfering with or disrupting an essential service, facility or system."

This Canadian definition of terrorism does not explicitly include the words "violence," but it is implied in the descriptive term "seriously harming or endangering." While the element of "innocent civilians" is not designated with particularity, the broad term "a person" and "people" implies civilians.

The element of intent is also not specified but merely implied vaguely in the words "an action is taken." Some insight into the element of intent implied in these words can be gleaned by looking at the list of specific acts of terrorism which Canadian law provides. Unlike the terrorism definition in United States law, the Canadian law lists specific terrorist acts, including the disruption of an

77. See Report from Department of Justice, October 15, 2001, on "Highlights of Anti-Terrorism Act" from the Minister of Justice of Canada, available at http://www.canada.justice.gc.ca/en/news/nr/2001/ doc_27787.html (last visited Feb. 1, 2003).

78. See infra Part III (F) for discussion of UN Definitions of Terrorism in Conventions, Protocols, and Resolutions. 
essential service, facility or system. It is interesting to note that in an effort to balance civil rights with the protection of national security, Canadian law does not include under the definition of a terrorist act the disruption of an essential service during a lawful protest or a work strike, if the action does not intend to cause serious harm to persons. Therefore, the emphasis on intent as a condition of terrorist activity in this context strongly supports the view that the element of intent is implied in the definition of terrorism under Canadian law. The, element of "fear, coercion or intimidation" is not specified explicitly but implied in the term "threatens." The Canadian definition specifically designates the purpose of the terrorist action as political, religious, or ideological and omits "military" and "ethnic."

Canadian law permits the designation of groups as "terrorist groups" if their activities meet the definition of terrorist activity.

The Canadian Criminal Code makes it a crime to knowingly collect or provide funds, either directly or indirectly, in order to carry out terrorist crimes. The maximum sentence for this offense would be ten years. It is a crime to knowingly participate in, contribute to or facilitate the activities of a terrorist group. Participation or contribution could include knowingly recruiting into the group new individuals for the purpose of enhancing the ability of the terrorist group to aid, abet, or commit indictable offences. The maximum sentence for the offense of participating or contributing would be ten years of imprisonment. The maximum sentence for facilitating would be fourteen years of imprisonment. Anyone who instructs another to carry out a terrorist act or an activity on behalf of a terrorist group ("leadership" offense) carries a maximum life sentence. Anyone knowingly harboring or concealing a terrorist would receive a maximum sentence of ten years.

A careful analysis of the Canadian definition of terrorism with respect to the five necessary elements shows that the definition is not as "clear" as the Canadian Department of Justice would have us believe. It is, however, more specific than United States law which does not list with particularity any acts of terrorism.

\section{F. United Nations' Definitions of Terrorism}

The United Nations and other international organizations have failed for decades to agree on a common universal definition of terrorism. United Nations General Assembly and Security Council resolutions repeatedly affirm their determination to combat terrorism in all its forms "irrespective of motive, whenever and by whomever committed."

79. G.A. Res. 1269, U.N. GAOR Security Council, 4053rd mtg. at 1, U.N. Doc. S/RES/1269 (1999). See G.A. Res. 1373, U.N. GAOR Security Council, 4385th mtg. at 14 7,8, U.N. Doc. S/RES/1373 (2001), which mandates that U.N. member states take measures to combat terrorism, and it creates a Counter 
The United Nations' definition of terrorism contained in a critical 1991 General Assembly Resolution reflects the consensus of the General Assembly and resolves the issue of whether terrorism constitutes a legal response by a state to safeguard its undeniable right to self-determination and self-defense. The General Assembly Resolution "unequivocally condemns, as criminal and unjustifiable, all acts, methods and practices of terrorism, wherever and by whoever committed." 80

The United Nations General Assembly's definition contained in its Resolution of 1991 has reappeared in several subsequent resolutions. This definition makes it clear that even though all people have certain rights-the right under racist regimes or alien domination to self-determination, the right to freedom and independence, and the right to struggle legitimately to achieve this end-notwithstanding these rights, peoples fighting against colonial domination may not resort to the acts proscribed in the antiterrorism conventions. ${ }^{81}$

In December 1999 the United Nations General Assembly Resolution $54 / 109^{82}$ defined terrorism as:

Criminal acts intended or calculated to provoke a state of terror in the general public, a group of persons or particular persons for political purposes are in any circumstances unjustifiable, whatever the considerations of a political, philosophical, ideological, racial, ethnic, religious or other nature, that may be invoked to justify them. ${ }^{83}$

Kofi Annan further reinforced the United Nations' blanket prohibition of terrorism: "Terrorism strikes at the very heart of everything the United Nations stands for. It presents a global threat to democracy, the rule of law, human rights and stability ...the methods and practices of terrorism [are] criminal and unjustifiable-whoever commits them and wherever they occur." ${ }^{\prime 4}$

The coexistence of a proliferation of anti-terrorism conventions and the recent increase of terrorist acts in 2001 and 2002 indicates the legislative failure by the United Nations to deter acts of terrorism. The international community has been trying to define terrorism since 1937 when the League of Nations first

Terrorism Committee to monitor the implementation of that resolution. See Jennifer Trahan, Terrorism Conventions: Existing Gaps and Different Approaches, 8 NEW ENG. J. INT'L \& COMP. L. ANN. 215, 239 (2002).

80. Michael P. Scharf, Book Review: Rebels With a Cause: The Minds and Morality of Political Offenders, 96, A.J.I.L. 276, 278 (Jan. 2002).

81. Id. at 278.

82. UN GAOR, 54th Sess., 76th mtg. at art. 6, U.N. Doc. A/RES/54/109 (1999).

83. Id.

84. "International Instruments Related to the Prevention and Suppression of International Terrorism, (United Nations 2001), in Preface. 
drafted the Convention for the Prevention and Punishment of Terrorism ${ }^{85}$ that was signed by twenty-four nations but ratified ultimately only by one nation', India. The United Nations began drafting anti-terrorism conventions in the 1960s because of a high incidence of aircraft hijackings. The United Nations has continued to draft specific anti-terrorism conventions for the past sixty-two years to respond to different kinds of terrorist attacks against civilians, diplomats, civilian aircrafts, commercial maritime navigation and sea-based platforms involving the use of explosives and weapons of mass destruction. ${ }^{86}$

There are currently seventeen specialized international United Nations conventions on terrorism, ${ }^{87}$ three international conventions on the control of

85. League Of Nations, Convention for the Prevention and Punishment of Terrorism, O.J. 19 at 23 (1938), League of Nations Doc. C. 546 (I). M.383 (1), 1937, V(1938).

86. BaSsiounl, supra note 1 , at 1 .

87. The U.N. Conventions on Terrorism, and one Draft Convention on the Suppression of Acts of Nuclear Terrorism are as follows:

Convention on the High Seas, Apr. 29, 1958, 13 U.S.T. 2312;

United Nations Convention on Law of the Sea, Dec. 10, 1982, 21 I.L.M. 1261;

Convention for the Suppression of Unlawful Acts Against the Safety of Maritime Navigation, Mar. 10, 1988, 27 I.L.M. 668;

Protocol for the Suppression of Unlawful Acts Against the Safety of Fixed Platforms Located on the Continental Shelf, IMO. Doc. Sua/Con/16/ Rev.1; 27 I.L.M. 685 (10 Mar. 1988);

Convention on Offences and Certain Other Acts Committed on Board Aircraft, Sept. 14, 1963, 2 I.L.M. 1042;

Convention for the Suppression of Unlawful Seizure of Aircrafts (Hijacking Convention), Dec. 16, 1970, 18 I.L.M. 1419;

Convention on the Prohibition of the Development, Production, Stockpiling and Use of Chemical Weapons and on their Destruction (CWC Convention], Jan. 13, 1993, 32 I.L.M. 800;

Convention for the Suppression of the Financing of Terrorism [Terrorism Financing Convention]; U.N. Doc. a/54/109 (9 Dec. 1999) 133 (16 Dec. 1970);

Convention for the Suppression of Unlawful Acts Against the Safety of Civil Aviation, Jan. 26, 1973, 10 I.L.M. 1151;

Protocol for the Suppression of Unlawful Acts of Violence at Airports Serving Civil Aviation [Montreal Protocol], Jan. 12, 1988, 27 I.L.M. 627;

Convention on the Prevention and Punishment of Crimes Against Internationally Protected Persons, Including Diplomatic Agents [Diplomats Convention], Dec. 14, 1973, 13 I.L.M. 41;

Convention Against the Taking of Hostages [Hostage-Taking Convention], Dec. 17, 1979, 18 1.L.M. 1456;

Convention on the Safety of United Nations and Associated Personnel [U.N. Personnel Convention], available at http://www.un.org/law/cod/safety.htm (last visited Feb. 1, 2003);

Convention on the Marking of Plastic Explosives for the Purpose of Detection, Mar. 1, 1991, 30 I.L.M. 721;

Convention for the Suppression of Terrorist Bombings [Terrorist Bombing 
weapons of mass destruction, two international conventions containing general United Nations provisions; two United Nations' Draft Comprehensive Conventions on terrorism; eight regional conventions against terrorism that have been developed by the Organization of American States, the Council of Europe, the South Asian Association for Regional Cooperation, the League of Arab States, the Organization of African Unity, the Commonwealth of Independent States and the Organization of the Islamic Conference. ${ }^{88}$ There are also international humanitarian law conventions on the prevention and punishment of torture which is related to terrorist acts. In addition, there are twenty-one international crimes conventions whose commission involves terrorism. Thus, terrorism is included in many different laws prohibiting crimes and human rights violations and covered under international humanitarian law conventions. Nevertheless, the increase in international terrorism and the magnitude of the tragic events that have occurred in the years 2001 and 2002 bear witness to the failure of these international conventions to deter the crime.

What is needed is not more laws but better enforcement of existing norms. Due to the political nature of terrorism, states have not been able to reach an agreement on a comprehensive convention that would include all types of terrorist acts and that would be applicable to state-sponsored terrorism. ${ }^{89}$ Moreover, since terrorism has been committed in the past by many state actors during the time of war or revolution, many states prefer to leave the definition of terrorism as vague as possible. More conventions will have to be adopted in the future to prevent against the threat or use of weapons of mass destruction, cyber-terrorism, and other new forms of terrorism. ${ }^{90}$ The many existing terrorist laws would be more efficiently collected in one comprehensive multilateral convention. Nevertheless, the protections that are needed against terrorism will not be adequately provided simply by the creation of new norms. What is needed is the effective enforcement of existing laws, the adoption of one universally-accepted definition of terrorism, the agreement by all nations that

Convention], U.N. Doc. A/Res/52/164 (9 Jan. 1998);

Convention on the Prohibition of the Development, Production and Stockpiling of Bacteriological (Biological) and Toxin Weapons and on Their Destruction [BWC Convention], Apr. 10, 1972, 11 I.L.M. 309;

Convention on the Physical Protection of Nuclear Material, IAEA Doc. C/225;1456 U.N.T.S. 101; 18 I.L.M. 1419 (3 Mar. 1980)

Convention on the Prohibition of the Development, Production, Stockpiling and Use of Chemical Weapons and on their Destruction (CWC Convention], U.N. Doc. A/Res/47/39; 1974 U.N.T.S. 3; 32 I.L.M. 800 (13 Jan. 1993)

Draft Convention on the Suppression of Acts of Nuclear Terrorism [Nuclear Terrorism Convention], U.N. Doc. A/AC.252/L.3 (28 Jan. 1997).

88. BASSIOUNI, supra note 1 , at xxviii.

89. Id. at $\mathrm{xxv}$.

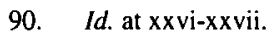


terrorism must be prohibited irrespective of its motivation, and the application of the existing laws to state-sponsored terrorist acts. ${ }^{91}$

In December 1999, the United Nations General Assembly adopted by consensus the text of a draft of the International Convention for the Suppression of the Financing of Terrorism in which terrorism was indirectly defined in the same terms as the United Nations General Assembly Resolution 54/109 above:

\begin{abstract}
Criminal acts intended or calculated to provoke a state of terror in the general public, a group of persons or particular persons for political purposes are in any circumstances unjustifiable, whatever the considerations of a political, philosophical, ideological, racial, ethnic, religious, or other nature, that may be invoked to justify them. ${ }^{92}$
\end{abstract}

This definition in the United Nations Convention for the Suppression of the Financing of Terrorism does not specifically refer to acts of violence but refers, instead, to "criminal acts." The definition arguably includes the element of targeting innocent civilians in the term "general public." It includes the element of intent by the words "intended or calculated to provoke." The requirement of coercion or intimidation is included in the term "terror." However, this definition does not include state-sponsored actors. Moreover, the definition expands the motivation of terrorism to almost any possible cause, other than military. The definition does convey very clearly that the root cause or motivation of the terrorist act does not provide any justification whatsoever for terrorism. In other words, according to the United Nations, the ends do not justify the means.

\title{
G. Scholars' Attempts at Definition of Terrorism:
}

One terrorism expert has produced a working definition of terrorism that still falls short of including all five elements: "Terrorism is defined as the calculated employment or the threat of violence by individuals, sub-national groups, and state actors to attain political, social, and economic objectives in the violation of law, intended to create an overwhelming fear in a target area greater than the victims attacked or threatened." 93

This definition does not specifically include the targeting of innocent civilians and limits the perpetrator's motivations to illegal political, social, and

91. WILKINSON, supra note 76, at 13: "The difference between state and factional terrorism is that the former is more lethal and may be antecedent to, and a contributory cause of, factional terrorism.... Guerrilla insurgents often use terrorism ...States conduct "terror" and substate organizations conduct "terrorism." Id. at 19.

92. UN GAOR, 54th Sess., 76th mtg. at art. 6, U.N. Doc. A/RES/54/109 (1999).

93. TERRORISM AND THE LAW, supra note 29, at 7. 
economic purposes. This definition opens the door for states to engage in terrorism by simply declaring that the purpose of the terrorist activity is justified by a legal political, social or economic goal.

Cherif Bassiouni, who is one of the world's leading experts in the field of international criminal law, has also proposed a definition of terrorism that specifically includes state-sponsored terrorism, which is conceived of not explicitly as a crime but rather as a "strategy," and which specifically excludes the intent of the perpetrator and the targeting of innocent civilians:

Terrorism is an ideologically-motivated strategy of internationally proscribed violence designed to inspire terror within a particular segment of a given society in order to achieve a power-outcome or to propagandize a claim or grievance, irrespective of whether its perpetrators are acting for and on behalf of themselves, or on behalf of a state. ${ }^{94}$

By referring to the "ends" as a "power outcome," a "claim" or a "grievance," Bassiouni's definition cleverly eliminates the consideration of the worthiness of the goals or the claimed justifications for terrorist acts. Arguably, the definition does not specifically include the element of intent. However, since the act is conceived of as a "strategy," which requires a mental process, the intent element is presumed. Moreover, the term "designed to inspire terror" evokes the pre-meditated intent of the actor. If the element of intent were absent from this definition, one could presumably be condemned as a "terrorist" if, in the course of a carefully conducted attack not specifically intended to produce fear and not specifically targeted at innocent civilians, the bomb blast did, in fact, cause fear in the population and cause the accidental injury of one or two civilians. The element of intent should be a necessary requirement in the definition of terrorism in order to permit justifiable attempts at self-defense not involving intentional terrorist acts.

Bassiouni's definition also does not include the targeting of "innocent civilians" but refers, instead, to "a particular segment of a given society." This broad designation of a particular segment of the population could include the military, especially if acts of "international terrorism" are claimed to arise in the context of a conventional war or armed conflict of an international or of a noninternational character. Bassiouni specifically states that international terrorism arises in the following contexts:

1. Armed conflicts of an international character or of a noninternational character: 
a) conventional wars;

b) wars of national liberation;

c) against settler regimes, the intended power outcome is either the removal of the settlers or transfer of power from settler group to indigenous population;

d) against foreign occupation and/or colonial regimes.

2. International political conflicts, which may or may not involve armed conflict or non-international character. ${ }^{95}$

By excluding the "innocent civilian" element, Bassiouni's definition of international terrorism would include an attack on combatants as well as noncombatants during an armed conflict. Arguably, an intentional attack on combatants during an armed conflict with the aim of inspiring fear (or terror) within the population of combatants should not be deemed "terrorism." It is war, pure and simple. Bassiouni's definition of international terrorism is brilliantly articulated, and would be enhanced if it included the element of "innocent civilians" in peacetime as well as wartime. Bassiouni uses the word "terror" rather than fear to define "international terrorism," thereby preserving the original denotation of the Latin word "terrore" (fear producing).

95. Id. at 18 .

96. Many scholars and journalists include "innocent civilians" in their definition of terrorism. See CALEB CARR, THE LESSONS OF TERROR (2002). Carr is a military historian who defines terrorism as "the contemporary name given to, and the modern permutation of, warfare, deliberately waged against civilians with the purpose of destroying their will to support either leaders or policies that the agents of such violence find objectionable." (cited in Stephen Yagman, Defining the Weapon of Terrorism: Frustrated People Without Another Method Resort to 'Politico-Military' Violence Instead, L.A. DAILY J. 6 (Mar. 12, 2002). See also William Pfaff, The Politics of Terrorism, or Civilians vs. Civilians, INT'L HERALD TRIBUNE 8, (Jan. 10, 2002), at op ed page. Pfaff defines as "a form of politico-military combat that attacks civilians ...because terrorists can't get at the political and military figures they really want to kill. Terrorism is the weapon that oppressed populations have always employed against those they consider their oppressors, usually because it is the only weapon available." Note that Yagman objects to Carr's insistence on "civilians:"

There have been numerous attacks on the military that surely can be characterized as terrorism: Japanese attack on Pearl Harbor, attack on American garrison at Kobat Towers in Saudi Arabia, the terrorist attack on the U.S.S. Cole, while it was moored in Yemen ...during France's horrific repression in Algeria, France regularly and openly employed military terrorism against innocent civilians to make concessions to France. American military bombing of a mental hospital in Grenada in ...1984 was allegedly fought to free American medical students studying in Grenada. America's bơmbing with Thatcher's assistance, of Libyan Col Muammar Al al Qaddafi's family's home in Tripoli to get even for what Reagan claimed was Qaddafi's terrorism in which one of Qaddafi's small children was murdered; President Clinton's bombing of a pharmaceutical factory in Sudan, where innocent night watchman was murdered.

These are all military terrorist acts conducted upon innocent civilians. 
Bassiouni's definition of terrorism requires the act of violence to be "internationally proscribed." He carefully lists fourteen specific acts of terrorism (including, aggression, war crimes, crimes against humanity, genocide, apartheid, unlawful human experimentation; torture, slavery and slave-related practices; piracy, and unlawful acts against the safety of maritime navigation; kidnapping of diplomats and other internationally protected persons; taking civilian hostages; serious environmental damage; or serious violation of fundamental human rights.) $)^{97}$ The advantage of this specific listing is the establishment of clarity and certainty in the law. However, the disadvantages are important to recognize. New forms of terrorist acts that develop with the advancement of technology, such as computer hacking, are not specifically included and may fall afoul of the definition. However, this list is very broad and seems to cover the unanticipated act of terrorism under such umbrella categories as "aggression," or "serious violation of fundamental human rights." Absent from this list, however, is "the use of weapons of mass destruction" which will necessarily, if not intentionally, inflict harm on "innocent civilians." Does that mean that the use of the A bomb during war time is a "terrorist" act because it necessarily resulted in the killing of innocent civilians? There may be a political reason to exclude the use of weapons of mass destruction from the list of proscribed terrorist acts.

\section{WHAT IS THE DIFFERENCE BETWEEN INTERNATIONAL AND DOMESTIC TERRORISM?}

International terrorism is covered under the seventeen United Nations multilateral anti-terrorism conventions that provide legal measures, in a piecemeal and ad hoc fashion, against different manifestations of international terrorist conduct like hijacking, hostage-taking, and violence against diplomats or internationally protected persons. For a terrorist act to be deemed "international," the act of violence must also contain an international element, be directed against an internationally protected target or violate an international norm. ${ }^{98}$ Internationally proscribed conduct that is applicable to terrorist violence includes aggression, war crimes, crimes against humanity, genocide, apartheid, unlawful human experimentation, torture, slavery, piracy, ${ }^{99}$ hijacking and sabotage of aircraft, kidnapping of diplomats, taking civilian hostages, serious environmental damage or serious violations of fundamental human rights. ${ }^{100}$

97. BASSIOUNI, supra note 1, at 18.

98. Id. at 17 .

99. MARITIME TERroriSM AND INTERNATIONAL LAW 43 (Natalino Ronzitti, ed., Martinus Nijhoff Publishers 1990) (discussing the legal relationship between piracy and maritime terrorism).

100. BASSIOUNI, supra note 1, at 18. 
Domestic terrorism is harder to define than international terrorism because domestic terrorism is usually included in state criminal statutes under acts committed by common criminals. ${ }^{101}$ Some states define terrorism as a crime, others define it as an "act of war," 102 and most states consider terrorism to be a method used to commit other more specifically defined crimes against the person or against property.

International terrorism, like domestic terrorism, is a method used to perpetrate other crimes, and as such international terrorism is arguably included under the category of other international crimes but only if the five necessary structural elements of terrorism are present. Typical tools of modern international terrorism are explosive and incendiary bombings, shooting attacks and assassinations, hostage-taking and kidnapping, hijacking, narco-terrorism, ${ }^{103}$ cyber-terrorism information warfare, ${ }^{104}$ and the use of nuclear, chemical, or bacteriological weapons. ${ }^{105}$ Terrorists can be convicted of committing war crimes, crimes against humanity, genocide, torture, and even piracy (i.e. the Achille Lauro incident), if they committed these crimes by using terrorist methods. Thus, international terrorism is an elusive concept that overlaps with other international crimes but which can be included in the definitions of these other crimes, if the five necessary elements are present, like the intentional use or threat of violence for political, religious or ideological purposes resulting in the harm of innocent civilians.

\section{Terrorism is Not Only a CRIME But A Method to ACHIEve SElF- DETERMINATION}

One of the underlying causes of the resurgence of terrorism in the 1960s and 1970s is the development of social movements dedicated to achieving selfdetermination or the revolutionary transformation of the socio-economic order and the concomitant belief by these groups that terrorism is an effective and legitimate weapon to realize their goals. ${ }^{106}$ In the 1990s in the course of tragic ethnic wars in the Balkans and in Rwanda, mass terror was used as a weapon on both sides of the respective conflicts, requiring the establishment of ad hoc

101. Id. at 19.

102. Raimo, supra note 31 , at 1481 (discussing the shift in US away from reactive counter-terrorism law enforcement methods and towards more pro-active techniques to fight international terrorism because the US now perceives of terrorist acts as acts of war).

103. DAvidS, supra note 6, at 2.

104. See Cyber TeRrorism ANd INFormation WARFARE: THREATS AND Responses (Yonah Alexander and Michael S. Swetnam, eds., Transnational Publishers, Inc. 2001).

105. Wilkinson, supra note 76, at 13. See also SUPERTERrorism: BIOlogiCAL, CHEMICAL, AND NUCLEAR (Yonah Alexander and Milton Hoenig, eds. 2001).

106. WILKINSON, supra note 76 , at 13. 
international tribunals, ${ }^{107}$ and later an international criminal court, ${ }^{108}$ to bring to justice the perpetrators of genocide, crimes against humanity and war crimes. ${ }^{109}$

Terrorism per se is not listed as a crime under the subject matter jurisdiction of the ad hoc tribunals. ${ }^{110}$ In the Statute of the International Criminal Tribunal for the Former Yugoslavia (ICTY), Article 5 defines crimes against humanity and includes in this category "crimes committed in armed conflict, whether international or internal in character, and directed against any civilian population, including murder, extermination, enslavement, deportation, imprisonment, torture, rape, persecutions on political, racial and religious grounds and other inhumane acts." Even though this description of crimes against humanity contains all five elements of the definition of terrorism, it fails to name or include "terrorism" as a "crime against humanity."

Similarly, the Statute of the ICTY at Art. 3 defines war crimes or "violations of laws or customs of war," but it does not include the term terrorism per se. Nevertheless, under the definition of war crimes, the Statute of the ICTY proscribes the "employment of poisonous weapons, the wanton destruction of cities, towns or villages, or devastation not justified by military necessity; an attack, or bombardment, by whatever means, of undefended towns, villages, dwellings, or buildings; and the seizure or destruction or willful damage done to institutions dedicated to religions, charity, and education, the arts and sciences, historic monuments and works of art and science." This definition of war crimes also contains most of the elements of terrorism (use of violence, with intent, to harm innocent civilians (i.e. "undefended towns"), but does not include the necessary elements of fear, intimidation and coercion for the purpose of accomplishing a political (military, ethnic, ideological or religious goal). Moreover, in order for terrorism to be a war crime, the terrorist act has to be perpetrated during an armed conflict. If these last two elements plus the requirement of an armed conflict were included in the act constituting a war crime, that war crime as defined above could also be deemed a terrorist act.

The Statute of the ICTY at Art. 4 defines "Genocide" as "acts committed with intent to destroy in whole or in part, a national, ethnical, racial or religious group." The definition of genocide does not specifically include "terrorism" per se. Nevertheless, if a genocidal act were perpetrated with the intent of furthering a cause by intentionally inspiring fear through violence committed

107. Secretary-General's Report on Aspects of Establishing an International Tribunal for the Prosecution of Persons Responsible for Serious Violations of International Humanitarian Law Committed in the Territory of the Former Yugoslavia, May 3, 1993, 32 I.L.M. 1159; Establishing the International Tribunal for Rowanda, Nov. 8, 1994, 33 I.L.M. 1598.

108. Rome Statute of the International Criminal Court, art. 1, available at http://www.un.org/law/icc/statute/99_corr/1.htm (last visited Feb. 1, 2003).

109. WILKINSON, supra note 76, at 48.

110. See Statute of the ICTY, supra note 107, at Art. 5 defining "Crimes Against Humanity." 
on an innocent civilian population, such a genocidal act would necessarily be a terrorist act.

Similarly, the Rome Statute of the International Criminal Court ${ }^{111}$ has long lists of elements of different crimes such as crimes of aggression, war crimes, crimes against humanity, and genocide, but terrorism per se is not specifically listed as a crime. Nevertheless, many of the criminal acts listed that can cause terror among the civilian population could arguably be included under the categories of aggression, war crimes, crimes against humanity and genocide, such as enforced disappearance of persons, rape, the crime of apartheid, and other inhumane acts of a similar character intentionally causing great suffering, or serious injury to the body or to mental or physical health. ${ }^{112}$

The implication of conceiving terrorism as a method (strategy, tool) rather than as a crime is that terrorism can be included in other international crimes of aggression, war crimes, crimes against humanity, genocide and piracy, or torture, if the acts of terror and violence also fulfill the five structural elements of the definition of terrorism.

\section{INTERNATIONAL CRIMES ARE ALSO METHODS OF COMMITTING TERRORISM}

Just as terrorism is both a crime and a method to perpetrate other crimes, the reverse is true--international crimes of genocide, war crimes, and crimes against humanity can, under the right circumstances, also be considered methods of terrorism intentionally designed to intimidate and cause fear in a given civilian population. ${ }^{113}$ The right circumstances constitute the presence of

111. Rome Statute of the International Criminal Court, supra note 108, and Preparatory Commission on the International Criminal Court, Finalized Draft of the Elements of Crimes, U.N. Doc PCNICC/2000/1/Add.2 (2000), available at http://www l.umn.edu/humanrts/instree/iccelementsof crimes.html (last visited Feb. 1, 2003).

112. Rome Statute of the International Criminal Court, supra note 108, at Article 7.

113. BASSIOUNI, supra note 1 , at xxvi.:

International crimes such as genocide, crimes against humanity, war crimes, and torture are strategies of terror violence designed to instill terror within a given civilian population. How else could one describe the policies and practices carried out in Cambodia, the former Yugoslavia, Rwanda, and Sierra Leone, to name only a few of the most egregious examples. However, these international crimes are a result of state policy and which are committed by state officials, i.e. the military, the police, other forces under the command of public officials. The commission of these crimes depend on the availability of state resources, financial and otherwise. Yet, these crimes are not considered part of what is commonly referred to as "terrorism" by the international community. The reason, as mentioned above, is that states, which are the regulators, have seen fit to not include themselves in the context of "terrorism." Nevertheless, international crimes committed by states which constitute terror-violence should be deemed part of that category. Id. 
the five structural elements of terrorism. Unless a genocidal act includes acts of violence, the intent to inspire fear in the civilian population for the purpose of accomplishing a political cause, the genocidal act will not be a terrorist act. Similarly, rape, ${ }^{114}$ torture, piracy, and other crimes can also be deemed methods of accomplishing terrorism only if the five elements of terrorism are present. Arguably, even if the subject matter jurisdiction of the ad hoc tribunals does not specifically cover "terrorism" under the list of triable crimes, terrorism as a method may, nevertheless, be included under the subject matter jurisdiction of the tribunal because it provides the means to perpetrate the specifically delineated crimes. ${ }^{115}$ This is also true of the International Criminal Court. But without a consensus about what terrorism means and without a commonality of values, some states prefer to keep the definition of terrorism in multilateral and domestic legislation as vague and ambiguous as possible. ${ }^{116}$ This will not prove to be an effective legal response to terrorism. Indeterminacy in the law, brought about by a vague or nonexistent definition of terrorism, can result in the multiplicity of interpretation and the instability of the legal system.

\section{IF TERRORISM IS NOT ONLY A CRIME BUT A METHOD OR AN ACT OF WAR, THEN WHAT COURT SHOULD TRY INTERNATIONAL TERRORISTS?}

Should international terrorists be tried in a military court, a United States District Court, an ad hoc international tribunal or a permanent international criminal court? ${ }^{117}$ These questions are left open by the failure of the international community to define terrorism or to include it as a crime in the jurisdiction of existing international courts. If terrorism is not listed specifically as a crime in the statutes of either of the two ad hoc tribunals (ICTY and ICTR) or in the statute of the new International Criminal Court, the question remains as to where international terrorists can be tried.

114. Catharine A. Mackinnon, Sex Equality: Rape Law 906 (Foundation Press 2001): "Rape in conflict is also used $s$ a weapon to terrorize and degrade a particular community and to achieve a specific political end. In these situations, gender intersects with other aspects of a woman's identity such as ethnicity, religion, social class or political affiliation. The humiliation of pain and terror inflicted by the rapist is meant to degrade not just the individual woman but also to strip the humanity from the larger group of which she is a part." Id.

115. See Michael P. Scharf, Editorial: The Case for an International Trial of the Al-Qaeda and Taliban Perpetrators of the $9 / 1$ Attacks, Newsletter of the Interest Group on International Organizations of the ASIL, at 12-15 (Spring 2002) (discussing the advantages and disadvantages of expanding the jurisdiction of the ICTY to cover terrorist acts committed on Sept. 11, 2002 in the United States and to include them under war crimes, crimes against humanity and genocide by simply amending the temporal and geographic jurisdictional limitation).

116. BASSIOUNI, supra note 1 , at $\mathrm{xxvi.}$

117. See Jennifer Trahan, Trying A Bin Laden and Others: Evaluating the Options for Terrorist Trials, 24, 3 Hous. J. OF INT'L. L. 475 (2002). 
In order to try terrorists in either of the two ad hoc international tribunals, the temporal and geographic limitations imposed on the subject matter jurisdiction of these tribunals would have to be expanded by amendment, and terrorism would have to be presumptively included under the definitions of crimes.

Even if the International Criminal Court included terrorist acts as crimes, the terrorist act of September 11, 2001 committed in the United States could not be adjudicated there for at least two good reasons. The United States has not ratified the Rome Treaty establishing the International Criminal Court, and the terrorist act occurred before the actual establishment of the International Criminal Court.

Trying terrorists in the United States District Courts may be a viable solution, but this solution is not without problems including the potential for undesirable disclosure of sensitive evidence that might endanger national security; the security of judges and witnesses; and the fairness of trying foreigners in an American court where a heinous terrorist act is committed on United States soil.

It is beyond the scope of this article to analyze the relative merits of adjudicating international terrorist suits in each of these tribunals, but it is noteworthy to recognize that the problem of where to try terrorists has arisen primarily because of the failure of the international community to establish a universally-accepted definition of terrorism and the failure of the courts to recognize that terrorism is actually included in other defined international crimes.

\section{The PARADOXES INHERENT IN THE MEANING OF TERRORISM}

The main problem in defining the term "terrorism" is not its overlap with other crimes but the paradox inherent in the meaning of the word. President Ronald Reagan has coined this paradox in the proverbial statement: "One man's terrorism is another man's freedom fighter" or the poetic parallelism articulated by the international law scholar Cherif Bassiouni: "What is terrorism to some is heroism to others." 118 The paradox is related to the distinction between illegal terrorism and legal revolutionary violence. The antinomy in the term "terrorism" is based on the coexistence of conflicting rights of self-defense and self-determination, on the one hand, and the fundamental right to the protection of human rights, on the other hand. Another manifestation of this paradox is the state's obligation to protect the national security of its people, which, if zealously enforced through overly broad legislation, may be in direct conflict with the state's obligation to protect its citizens' civil liberties.

118. Bassiouni, supra note 1 , at 15 . 
Article 51 of the United Nations Charter provides the right to individual or collective self-defense if an armed attack occurs against a member of the United Nations. Moreover, every nation has a right to self-determination. In 1979 Algeria, Libya and a few other countries wanted the United Nations to make an exception in one of its multilateral conventions ${ }^{119}$ against hostage taking for national liberation movements ${ }^{120}$ in which peoples are fighting against colonial domination and alien occupation and against racist regimes in the exercise of their right of self-determination. However, the Western countries rejected this demand on the grounds that even armies may not take civilian hostages because such an act would violate the Geneva Convention. There must be a balance established between the right of a democracy to defend itself against terrorism and the preservation of civil liberties and human rights. ${ }^{121}$ The difficulty to achieve this delicate balance has resulted in the proliferation of global treaties and declarations aimed at combating international terrorism and the abysmal failure by the international community to define terrorism and to prohibit statesponsored terrorist acts. The time has come to take a more active approach to defining the term terrorism.

\section{CONCLUSION}

The semiotic approach to defining terrorism has uncovered five basic structural elements which must be present in order to identify a violent act as terrorism. The paradoxical nature of the concept of terrorism renders the establishment of an acceptable definition difficult but not much different from the work that judges must do in the typical "hard case," as defined by Ronald Dworkin. ${ }^{122}$ Balance is the essence of the law iconographically represented by the scales of justice. Judges understand the sensitive nature of prioritizing two conflicting rights of equal importance. Who is to say that the right of selfdetermination or the right of self-defense against an armed attack is more important than the right of civilians to live in a safe environment, to enjoy their own fundamental human rights and basic civil liberties?

It is possible to de-center this paradox and to reduce the definitional difficulty by proposing a categorical prohibition on the use of terrorism, no matter how lofty the purpose may be, no matter how worthy the political or

119. International Convention Against the Taking of Hostages, U.N. Doc. A/Res/34/146(1979), Article 12.

120. See Malvina Halberstam, How Serious Are We About Prohibiting International Terrorism and Punishing Terrorists? 11, I THE JEWISH LAW (1996) (discussing the exception for national liberation movements in Article 12 of the International Convention Against the Taking of Hostages, U.N. Doc. A/Res/34/146 (1979)).

121. See Gross, supra note 11 , at 89 .

122. RONALD DWORKIN, TAKING RIGHTS SERIOUSLY 81-130 (1977). 
ideological cause may seem to those oppressed by tyrannical regimes. There is no justification for terrorism. It is not defensible to argue that terrorism needs to be viewed from a political context and that the "motivation" of the actor and the sociological context in which the act occurs must be taken into consideration. Such an approach would legitimize terrorist acts by claiming that the ends justify the means. The Macchiavelian principle that the ends justify the means simply does not comport with the generally accepted principles of the rule of law. 